\title{
CAPITAL STRUCTURE AND ITS DETERMINANTS IN NEW ZEALAND FIRMS
}

\author{
Nirosha Hewa Wellalage ${ }^{1}$, Stuart Locke ${ }^{2}$ \\ Department of Finance, The University of Waikato, Hamilton 3240, New Zealand \\ E-mails: ${ }^{1}$ nuh1@waikato.ac.nz (corresponding author); ${ }^{2}$ smlocke@waikato.ac.nz \\ Received 13 October 2011; accepted 26 March 2012
}

\begin{abstract}
The current study aims to empirically explore the relationship between firm characteristics, corporate governance and capital structure in New Zealand's large listed companies. Eight years of data for 40 firms listed on the NZX50 Stock Exchange, are collected and observations are analysed using a conditional quantile regression. This study finds firm-specific characteristics rather than corporate governance variables play a significant role in determining firm leverage levels. The results indicate that finance policies need to vary across firm type and firm characteristics, and should match with the different borrowing requirements of listed firms.
\end{abstract}

Keywords: capital structure, firm characteristics, corporate governance, quantile regression, financial policy, New Zealand.

Reference to this paper should be made as follows: Wellalage, N. H.; Locke, S. 2013. Capital structure and its determinants in New Zealand firms, Journal of Business Economics and Management 14(5): 852-866.

JEL Classification: G32.

\section{Introduction}

This study investigates the capital structure of New Zealand's large listed companies on the New Zealand Stock Exchange. A number of empirical studies find that firm capital structure is related to firm characteristics; namely firm size, tangibility, profitability, tax-shield, growth, liquidity, firmrisk level and industry type (Fattouh et al. 2008; Saksonova 2006; Fattouh et al. 2005; McConnell, Pettit 1984). Moreover, recent literature focuses on the subject matter of capital structure decisions, and association of corporate governance practices (Berger et al. 1997; Wen et al. 2002). Therefore, this study considers how firm characteristics and corporate governance practices both impact in capital structure choice in New Zealand listed firms.

New Zealand provides an interesting case study for corporate financing policy and corporate governance. Although, the current $28 \%$ corporate tax rate reduces tax incentives for using debt in New Zealand's large corporations, this tax rate is high compared to similar sized OECD countries whose average is $25 \%$. Therefore, tax incentives play a significant role in determining capital structure in New Zealand firms. This is con- 
firmed by Business Finance in New Zealand (2004), which indicates that New Zealand firms finance their assets more by debt than equity. Further, it shows the mean ratio of New Zealand firms debt-to-assets ratio is 0.60 . This may be due to the broad range of financial instruments available in the New Zealand financial market. Smith, Chen and Anderson (2010) report, because of the low level of market anomalies and a developed banking system, New Zealand firms issue significantly more debt than equity. Though firms enjoy high debt levels, the identity of optimal level of debt is important in New Zealand firms because the country's bankruptcy laws do not protect business owners as much as USA laws do. As an example, New Zealand does not provide homestead exemption or future earnings exceptions in their bankruptcy law. A personal cross guarantee requirement in the bank lending processes has worsened this problem. Additionally, the New Zealand Securities Commission introduced a principal-based voluntary corporate governance code in 2004, this recent corporate governance changes have also had significant impact on the capital structure choices of New Zealand firms.

The current study aims to empirically explore the relationship between firm characteristics, the corporate governance practices and the capital structure of New Zealand listed companies by applying the method of conditional quantile regression. This quantile regression sketches the entire distribution of leverage, conditional on a set of explanatory variables. Moreover, since this study sample comprises large outliers and the distribution of the disturbances is non-normal, quantile regression is robust for this study.

This paper makes a number of contributions to firm capital structure research. First it provides evidence that firm characteristics and corporate governance practices impact on firm capital structure choice. Secondly, most existing studies use data from listed companies in large markets such as the USA and UK, but it is important to consider how Australasian market firms, firm characteristics and corporate governance practices relate to capital structure choice. Finally, the econometric analysis is more robust than prior research due to the use of the quantile regression analysis. Quantile regression examines the whole distribution of the capital structure distribution of firms rather than a single measure of the central tendency of the capital structure distribution.

The next section of the paper reviews prior research. This is followed by a discussion of the data, variables, method and procedures used in this present study. The findings and implications then follow.

\section{Literature review}

Since the Modigliani and Miller (1958) seminal study of the debt irrelevance proposition in a perfect capital market, financial economists have introduced four new theories to explain the variations in debt ratios across firms. Pecking-order theory is based on the idea of information asymmetry between managers and investors (Mayers 1984; Ross 1977). The theory proposes that firms prefer to finance new investment by first seeking internal retained earnings, then debt and finally with an issue of new equity. Tax-benefits trade-off theory is based on the idea that firms will seek to maintain optimal capital structure by balancing the costs and benefits from debts (DeAngelo, Masulis 1980). The 
benefits and costs can be obtained in different ways. From a "tax-benefits" perspective, firms can reap the advantages of having debt to get tax benefits. From an "agency" perspective, debt mitigates the agency problem between shareholders and managers. The third capital structure relevant theory is agency costs theory, which explains conflicts between managers and shareholders and bondholders (Jensen, Meckling 1976). According to Jensen and Meckling (1976), the importance of agency costs of equity arises with the separation of ownership and control of firms. Hence, a high level of leverage may be used as disciplinary device to mitigate managerial cash flow waste. Moreover, agency costs can arise between debt and equity holders due to risk of default. The next theory is market timing theory. First discussed by Myers (1984), and it states that the strategy of buying and selling decision of capital is based on market timing benefits. If neither debt nor equity markets are favourable, managers may defer issuances. Alternatively if any market shows an extremely favourable situation, managers raised capital though firm does not need to raise capital in currently. Based on the above four theories, the factors impacting on firm capital structure can be categorised as three major categories: firm specific characteristics, industry specific characteristics, and market related characteristics. This study will consider possible firm-specific characteristics: firm liquidity, tangibility, growth, risk, size, non-debt tax-shield, the industry in which the firm operates, non-executive directors' percentage, director ownership and foreign ownership.

Firm Size. Firm size has become an important determinant of capital structure. Due to higher bankruptcy costs, lower marginal corporate tax rates and high asymmetry information, small firms have proportionately less debt than larger firms (Michaelas et al. 1999). Studies of the determinants of New Zealand firm's capital structure have also confirmed that large companies tend to use more leverage than small firms. As an example, Business Finance in New Zealand (2004) explains only 29\% of businesses with one-to-five employees request debt financing compared with $40 \%$ of large firms. This may be due to the following reasons. First, larger firms may have a higher credit rating than their smaller counterparts and therefore it is easier to access external financing due to lower information asymmetry (Subadar 2011). Secondly, larger firms are likely to have higher debt levels to maximise the tax benefits from debt (Rajan, Zingales 1995). Cassar (2004) argues that due to that high cost of external borrowing, small firms may prefer lower level of debts than larger firms. This is in line with Titman and Wessels (1988) who explain that smaller scale financing results in relatively higher transaction costs. Based on agency costs theory, Um (2001) argues that due to lower monitoring costs in larger firms, larger firms tend to be using more debt than smaller firms. However, using quantile regression, Fattouh et al.(2008) find firm size has significant positive coefficient in lower quantiles of leverage and after the $75^{\text {th }}$ quantile it changes, indicating regardless of firm size, if firms become highly leveraged they may no longer be able to borrow externally.

Tangibility. Firms with high a proportion of tangible assets will be in a position to provide more collateral in their debts. Seventy-two percent of New Zealand's external debt financing is provided by banks (Business Finance in New Zealand 2004). Therefore, the collateral requirements of banks have a significant effect on determining capital 
structure in New Zealand firms. This is confirmed by Business Finance in New Zealand (2004) which indicates that due to insufficient collateral, 31\% of debt requests were rejected in New Zealand. Agency theory suggests that issuing debt secured by collateral may reduce the information asymmetry-related costs in financing. Tangible assets always reduce financial distress costs due to their high liquidation value (Harris, Raviv 1991; Titman, Wessels 1988). Trade-off theory, explains that a firm's tangible assets can be used as debt collateral. Prior research finds a positive relationship between firm leverage and its collateral (Frank, Goyal 2002; Um 2001). Nuri (2000) finds a positive relationship between firm tangibility and long-term debt. Bevan and Danbolt (2000, 2002), Van-der-Wijst and Thurik (1993), Stohs and Mauer (1996) find a positive relationship between tangibility and long-term debt. Therefore, firms with more tangible assets have more opportunity to issue more debts.

Liquidity. As predicted by the pecking-order model, Saksonova (2006), Frieder and Martell (2006), Lipson and Mortal (2009) find a negative relationship between firm leverage ratios and firm liquidity, indicating that firms with more liquid equity carry less debt. This may be because a high level of liquidity limits a firm's ability to commit to specific causes of action, therefore limiting external borrowings. Based on agency costs theory, Myers and Rajan (1998) explain that when agency costs of liquidity are high, outside creditors limit the amount of debt financing available to the company. However, as predicted by trade-off theory, Harris and Raviv (1991), Al-Najjar and Taylor (2008) find a positive relationship between firm leverage and liquidity ratio. This may be explained as liquidity assets can increase collateralisability of assets, which positively affect external borrowings.

Non-debt tax-shield - Apart from interest expenses, other items known as non-debt tax-shields can help reduce in tax expenses. Firm depreciation is the common nondebt tax-shield used in capital structure studies (Bauer 2004; Noulas, Genimakis 2011). DeAngelo and Masulis (1980) explain that non-debt tax shields work as a substitute for the tax benefits for debts. In line with the above findings, Fattouh et al. (2005) using South-Korean firms, confirm that when firms use high depreciation as a non-debt tax shield, they obtain lower debt levels. Moreover, Prahalathan (2007), using 19 manufacturing companies listed on the Sri Lanka Stock Exchange, finds a significant negative relationship between non-debt tax shields and firm leverage levels.

Growth. Prior studies find mixed results for firm growth level and debt level. Brailsford et al. (2002) explain firm growth rate as proxy for available internal funds. Consequently, based on pecking-order theory, firms with high growth rate have a negative relationship with external financing (Myers, Majluf 1984). Moreover, according to trade-off theory, firms with high growth rates tend to use less external financing, because growth rate is non-collateralised. Additionally, based on agency theory, Myers (1977), Al-Najjar and Taylor (2008) find that firms with high growth rates tend to use less debt to mitigate agency conflicts that arise due to high information asymmetry. Rajan and Zingales (1995) find two main reasons for a negative relationship between firm growth level and debt level. First, it is expected that as growth opportunities increase, the cost of financial distress also increases. Secondly, firms prefer to issue overvalued 
equity. However, Booth et al.(2001) find a positive relationship between firm leverage level and firm growth, indicating high growth firms will tend to look outside the firm to finance. This is consistent with pecking-order theory. Um (2001) argues, based on pecking-order theory, that growing firms choose debt rather than equity. Pandey (2001) finds a significant positive relationship between growth and long- and short-term debt in Malaysian firms.

Risk. Based on both pecking-order and trade-off theories, a firm's volatility of earnings (operating risk) increases probability of default because debt holders consider a firm's future earnings as protection for debt (Mehran 1992). Therefore, high risk firms may have a negative impact on firm leverage levels. Aligned with that, Subadar et al. (2010) find a significant negative relationship between Mauritius financial firms' risk and leverage levels. This is consistent with McConnell and Pettit (1984), who explain that high risk firms have higher probability of bankruptcy because they tend to have less gearing. In contrast, agency cost theory predicts a positive relationship between risk and leverage, because risk intensifies a negative impact on asymmetric information (Schoubben, Hulle 2004). However, limited empirical studies find a significant positive relationship between firm risk and leverage ratio (Jordan et al. 1998; Michaelas et al. 1999). This may be due to distressed firms preferring to borrow more external financing to overcome bankruptcy.

Director ownership. Prior studies suggest that firm ownership structure has a significant influence on the desire for firm control, which has subsequent implications for financing. However, the exact relationship between director ownership and capital structure is inconclusive (Brailsford et al. 2002). Firms with higher director ownership are reluctant to have external financing and their debt levels can be lower (Agca, Mansi 2006). Further, Berger et al. (1997) using US public corporations suggest that managerial entrenchment leads to debt avoidance. However, consistent with agency costs theory, Kim and Sorenson (1986) and Mehran (1992) find a significant positive relationship between firm board ownership and leverage levels, indicating closely-held firms reduce the information asymmetry problem. Consequently, they can more readily obtain debt.

Foreign Ownership. With foreign ownership, an increase in leverage is expected with lower cost of debt due to a firm's increased ability to access to new external funds on more favourable terms (Gurunlu, Gursoy 2010). However, in line with Jensen (1986) and agency theory, Wiwattanakantang (1999) argues that due to the geographical distance of foreign owners, the level of misalignment between owners and managers can be high. Hence, firms with foreign ownership may adopt less debt financing. This result is further confirmed by Gurunlu and Gursoy (2010) who find a significant negative relationship between foreign ownership percentage and long-term debt of companies listed on the Istanbul Stock Exchange. On the other hand, using Canadian listed companies, King and Santor (2008) find there is no significant impact on foreign ownership and company leverage levels.

Non-executive directors. In recent decades regulations have emphasised the importance of board independence and non-executive directors on company boards (Higgs Report 
2003). Jensen (1986), Berger et al. (1997) and Abor (2007) find a positive relationship between non-executive directors' percentage on boards and firm leverage ratios. This indicates that outside directors have a positive impact on corporate leverage. One possible explanation for that is that non-executive directors ensure managerial accountability of shareholders, reduce agency conflicts of shareholders and managers, which leads to firms adopting high-debt policies. Nevertheless, Wen et al. (2002) find a significant negative relationship between non-executive directors and firm leverage. The possible explanation for that is non-executive directors actively monitor managers which causes these managers to adopt low external financing policies.

\section{Data}

\section{Sample}

This study collected data from Thomson One Banker database for the top 50 publicly listed companies on the New Zealand Stock Exchange under the NZX50 category for the period 2003-2010. The NZX50 companies are the largest 50 companies listed on the New Zealand Stock Exchange by free float market capitalisation. One major reason for starting the data collection from 2003 is because the NZX50 was introduced in New Zealand that year. Another reason is New Zealand recent corporate governance reforms started in 2003 and in 2004 the New Zealand Securities Commission introduced a voluntary principal-based corporate governance code. Though this code is a complyor-explain-type code, most listed companies' follow the proposed corporate governance practices in New Zealand. This study excludes all financial companies, because the nature of their liabilities is different from non-financial firms. From that sample, only 40 companies provided all the required data from all years in the range, 2003-2009. The final sample represents $80 \%$ of the mean number of firms listed in the NZX50 index.

\section{Dependent variables}

Following empirical evidence of prior studies, this study uses the most traditional measure as leverage proxy - the ratio of total liabilities divided by the total assets (Saksonova 2006).

\section{Explanatory variables}

To capture the corporate governance effect on firm capital structure, this study included foreign share ownership (FOREIGN), director share ownership (DOWN) and percentage of non-executive directors (PNED). Prior empirical studies identify firm-specific characteristics such as firm size, assets tangibility, growth rate, liquidity, non-debt tax shield and risk as the main determinants of firm capital structure (Rajan, Zingales 1995; Ramlall 2009). From the above independence variables, firm size, tangibility, growth rate, risk and liquidity can be interpreted as proxies for agency costs or other costs that arise due to asymmetric information (Fattouh et al. 2008). Moreover, trade-off theory explains capital structure influence by taxes. All the variables in this study are based on book values. This study also includes six dummy variables to capture the industryspecific effects. Following prior literature, firm size is calculated by natural logarithm of total assets (Michaelas et al. 1999; Titman, Wessels 1988). The tangibility ratio is 
calculated as total fixed assets to total assets. Following Fattouh et al. (2008) to measure growth opportunities, this study uses annual growth of the firm's total sales. Following Bradley et al. (1984), this study measures firm risk as the standard deviation of the annual earnings, scaled by the average value of the total assets over time. The ratio of current assets over current liabilities is considered the liquidity (LIQUID) variable in this study. Non-debt tax shield is calculated as the ratio of total depreciation to total assets. This study also includes the percentage of shares held by foreigners and percentage of shares held by directors. Moreover, percentage of non-executive directors is calculated as the ratio of total non-executive directors to total assets.

Table 1. Descriptive statistics

\begin{tabular}{lcccccccc}
\hline \multicolumn{1}{c}{ Variables } & Obs & Mean & Median & Std & Min & Max & Skewness & Kurtosis \\
\hline DEBTASSETS & 280 & .4399522 & 0.433792 & .2276556 & 0 & 1.315084 & .3931158 & 3.08948 \\
\hline SIZE & 280 & 5.314568 & 5.413003 & .9539011 & 2.663701 & 6.91782 & -.6135989 & 2.965213 \\
\hline TANG & 280 & .5276358 & 0.473862 & .5676104 & 0 & 8.173598 & 8.799369 & 118.7772 \\
\hline LIQUID & 280 & 2.295501 & 1.450474 & 3.267381 & 0.08458 & 29.05655 & 4. & 32.05645 \\
\hline TAX & 280 & .0644478 & 0.035693 & .1395774 & -.013548 & 1.128158 & 5.459117 & 36.4116 \\
\hline GROWTH & 240 & .2027083 & 0.046427 & .8381288 & -.8165842 & 8.513044 & 6.681953 & 57.64042 \\
\hline RISK & 280 & .1031871 & 0.049498 & .2381227 & 0 & 3.054701 & 8.447098 & 93.94616 \\
\hline DOWN & 280 & .168316 & 0.040454 & .233664 & 0 & .9755613 & 1.566797 & 4.633394 \\
\hline FOWN & 280 & .0614643 & 0 & .1192464 & 0 & 1 & 2.486686 & 9.393099 \\
\hline PNED & 280 & .6398781 & 0.732143 & .3247655 & 0 & 1 & -.8555195 & 2.570121 \\
\hline
\end{tabular}

Table 1 reports descriptive statistics for the sample data. The mean value of total debt to assets ratio is 0.44 . This leverage proxy indicates high use of corporate debt in New Zealand listed companies. This is in line with Gunasekarage et al. (2006) who explain that the average debt to assets ratio for large companies in New Zealand is 48\%. Moreover, Alves and Ferreira (2011) using New Zealand firms from 1996-2001 indicate that New Zealand firms' debt to assets ratio (book value) is $42 \%$. These findings indicate that large New Zealand companies rely on debt as source of finance. Descriptive statistics indicate mean value of firm liquidity is 2.295 . This may be because high investor protection of New Zealand companies leads them to increase their liquidity levels. Firm tangibility assets vary between $0 \%$ to $82 \%$ and mean value is $52.7 \%$. This indicates a fairly large proportion of total assets come from fixed assets. However, this value is significantly less than South Korean market findings by Fattouh et al. (2005). The nondebt tax shield variable indicates the mean value of TAX variable is 0.064 . This value is approximately two times higher than the emerging market study by Wiwattanakantang (1999). Results indicate that sample firm growth rate is 0.2. This low growth rate is consistent with Gurunlu and Gursoy (2010) who state that developed market firms' growth rates are significantly low. According to Table I, the RISK variable indicates a 
mean value of 0.103 . This value is smaller than emerging market findings by Sheikh and Wang (2011). This value indicates less volatility in New Zealand firm cash flow. Though the mean value of DOWN variable is $16.8 \%$, the median value indicates $50 \%$ of sample firms have only $0.4 \%$ of director ownership. Not surprisingly, the study sample shows low foreign ownership in NZX50 firms. The mean foreign ownership is only $6.14 \%$ and median value indicates $50 \%$ of large firms have no foreign ownership. This confirms that trend towards more New Zealand local ownership and less foreign ownership in the New Zealand Stock Exchange in last five years. As a result of recent corporate governance reforms, New Zealand listed firms now have more non-executive directors on their boards. Table 1's descriptive statistics confirm the above statement and shows the mean value of non-executive directors in NZX50 firms is 64\%.

If the value of skewenss is zero and kurtosis is less than 3 , data are normally distributed. According to Mukherjee et al. (1998) if the skewness value is equal to zero, the distribution of the data is symmetric. If the kurtosis value is less than 3 , tails of the data are thin. Table 1 shows, except for SIZE and PNED, all other variables skewness values are not closer to zero and their kurtosis is greater than 3 . Therefore, all other variables (except SIZE and PNED) are not systematically distributed. This indicates all observations have extreme values.

\section{Methodology}

Considering the descriptive statistics, one of the important issues in this data sample is that it contains large outliers and distribution of the disturbances is not normal. To further check normality for each variable this study uses the Jarque-Bera normality test. The result indicates that except for SIZE and PNED all other variables can reject the null hypothesis that the data are normally distributed. This result confirms that applying a conditional mean estimator is not appropriate for this sample data set. Hence, OLS regressions produce biased and inefficient estimates. Conversely, quantile regression is more powerful than OLS regression, because it produces separate estimates for all conditional quantiles of a response variable's distribution (Ramdani, Witteloostuijn 2010). Further, they explain quantile regression works better than OLS regression, especially for skewed data, unequal variance (heteroscedasticity) and existence of outliers.

Quantile regression as introduced by Koenker and Bassett (1978) seeks to complement classical linear regression analysis. Quantile regression essentially transforms a conditional distribution function into a conditional quantile function by splitting it into segments. In OLS, modelling a conditional distribution function of a random sample $\left(y_{1}, \ldots . . y_{n}\right)$ with a parametric function $\mu\left(x_{i}, \beta\right)$ where $x_{i}$ represents the independent variables, $\beta$ the corresponding estimates and $\mu$ the conditional mean, can cause the following minimization problem:

$$
\min \beta \in R \sum_{i=1}^{n}\left(y_{i}-\mu\left(x_{i}, \beta\right)\right) 2 .
$$

Obtains the conditional expectation function $\mathrm{E}\left[\mathrm{Y} \mid x_{i}\right]$ can proceed in quantile regression. The central feature thereby becomes $\rho \tau$, which serves as a check function. 


$$
\rho_{\tau}=\left\{\begin{array}{cc}
\tau * x & \text { if } x \geq 0 \\
(\tau-1) * x & \text { if } x<0
\end{array}\right\} .
$$

In quantile regression one minimizes now following function:

$$
\min \beta \in r \sum_{i=1}^{n} \rho_{\tau}\left(y_{i}-\in\left(x_{i, \beta}\right)\right) .
$$

Here, in contrast to OLS, the minimization is done for each subsection defined by $\rho \tau$, where the estimate of the $\tau$ th-quantile function is achieved with the parametric function $\xi(x i, \beta)$ (Koenker, Hallock 2001). Additionally, to confirm the robust results, this study used a matrix bootstrap method to obtain estimates of the standard errors for the coefficients in quantile regression under many forms of heterogeneity. Construction of confidence intervals based on the quantile regression estimator can be greatly simplified by using the bootstrap. Further, based on a Monte Carlo study, Buchinsky (1998) explains that the design matrix bootstrap method performs well with a relatively small sample size and is valid under different forms of heterogeneity.

\section{Results}

Table 2 indicates the regression results for debt to assets ratio. Column II-VI shows quantile regression results for $\theta=0.05, \theta=0.25, \theta=0.50, \theta=0.75, \theta=0.90$ respectively. The quantile regression results indicate that the effects of capital structure variables and firm size variable differ across the quantiles in the conditional distribution of firm leverage level. To further illustrate, quantiles are visualised in Fig 1.

Figure 1 indicates that firm growth has the largest positive effect around $\theta=.01$, being significantly small in higher quantiles. This may be consistent with pecking order theory; firms with higher growth opportunities may use less debt to prevent any problems with under-investment or agency conflicts between lenders and owners. Furthermore, according to the Myers (1984), this may be due to high interest rates or restrictive covenants that discourage debt intakes in growing firms. Consistent with Fattouh et al. (2008), with higher leveraged firms the marginal agency costs associated with non- collateralisable assets increases and this acts as a disincentive to leverage.

As can be seen in Table 2, tangibility is negatively and significantly throughout all quantiles. Overall, this finding is opposed to trade-off theory, which explains firm tangibility has a positive impact on firm debt capacity. However, this finding is consistent with Morellec (2001), Myers and Rajan (1998) and Venkiteshwaran (2011), who explain when firms can engage in ex-post asset sales or in transformation of these assets, then this higher liquidity leads to reduction in a firm's external borrowings. That may be because when agency costs of liquidity are high, outside creditors limit the amount of debt financing available to the company. Further, it may be that low information asymmetry associated with tangible assets makes equity issuances less costly. Hence, firms maintain low debt ratios with high tangibility. Though the non-debt tax shield is negative in all parts of the distribution, the TAX variable is significant only in higher quantiles. This finding is consistent with Fattouh et al. (2005) who posit that the rela- 
Table 2. Quantile regression results for debt to assets ratio

\begin{tabular}{|c|c|c|c|c|c|}
\hline \multirow{2}{*}{$\frac{\text { Variables }}{\text { (I) }}$} & \multicolumn{5}{|c|}{ Quantile regression } \\
\hline & Q 0.05 (II) & Q 0.25 (III) & Q $0.50(\mathrm{IV})$ & Q $0.75(\mathrm{~V})$ & Q $0.90(\mathrm{VI})$ \\
\hline $\begin{array}{c}\text { No of } \\
\text { Observations }\end{array}$ & 280 & 280 & 280 & 280 & 280 \\
\hline TANGI & $\begin{array}{l}-.0265791 \\
(.0977807)\end{array}$ & $\begin{array}{l}-.1549782 * * \\
(.0613833)\end{array}$ & $\begin{array}{l}-.1942842 * * * \\
(.0708347)\end{array}$ & $\begin{array}{l}-.1732706^{*} \\
(.0747115)\end{array}$ & $\begin{array}{l}-.1108594 * * \\
(0521341)\end{array}$ \\
\hline LIQUID & $\begin{array}{l}-.0400715^{* * *} \\
(.0045406)\end{array}$ & $\begin{array}{l}-.0450258^{* * *} \\
(.00418)\end{array}$ & $\begin{array}{l}-.035162 * * * \\
(.0059192)\end{array}$ & $\begin{array}{l}-.0251844 * * * \\
(.006387)\end{array}$ & $\begin{array}{l}-.0286323 * * * \\
(.0050771)\end{array}$ \\
\hline TAX & $\begin{array}{l}-.0298125 \\
(.134315)\end{array}$ & $\begin{array}{l}-.0455199 \\
(.142956)\end{array}$ & $\begin{array}{l}-.1365707 \\
(.1581284)\end{array}$ & $\begin{array}{l}-.2551205^{*} \\
(.137951)\end{array}$ & $\begin{array}{l}-.658024 * * * \\
(.0619095)\end{array}$ \\
\hline GROWTH & $\begin{array}{l}.0178309 \\
(.0204363) \\
\end{array}$ & $\begin{array}{l}.0161688 \\
(.0188976) \\
\end{array}$ & $\begin{array}{l}.0048234 \\
(.0193602) \\
\end{array}$ & $\begin{array}{l}-.0112239 \\
(.0137618) \\
\end{array}$ & $\begin{array}{l}-.0105733 \\
(.0122369) \\
\end{array}$ \\
\hline RISK & $\begin{array}{l}-.0946318 \\
(.0598239)\end{array}$ & $\begin{array}{l}-.1432232 * * \\
(.0653027)\end{array}$ & $\begin{array}{l}-.0310136 \\
(.0485831) \\
\end{array}$ & $\begin{array}{l}-.0813552 * \\
(.0345773)\end{array}$ & $\begin{array}{l}-.2362505^{* * *} \\
(.0208983)\end{array}$ \\
\hline DOWN & $\begin{array}{l}.0002938 \\
(.0008205)\end{array}$ & $\begin{array}{l}-.0003709 \\
(.0008964)\end{array}$ & $\begin{array}{l}-.0009925 \\
(.0009049)\end{array}$ & $\begin{array}{l}-.0007433 \\
(.0007493)\end{array}$ & $\begin{array}{l}-.0006002 \\
(.0003895)\end{array}$ \\
\hline FOWN & $\begin{array}{l}.2242476 \\
(.1916799)\end{array}$ & $\begin{array}{l}.1314159 \\
(.1888131)\end{array}$ & $\begin{array}{l}.0143518 \\
(.165347)\end{array}$ & $\begin{array}{l}.0549394 \\
(.1272515)\end{array}$ & $\begin{array}{l}-.2481139 * * * \\
(.0639459)\end{array}$ \\
\hline PNED & $\begin{array}{l}.0077213 \\
(.0989823) \\
\end{array}$ & $\begin{array}{l}.0345402 \\
(.0584527) \\
\end{array}$ & $\begin{array}{l}-.0115849 \\
(.0615859) \\
\end{array}$ & $\begin{array}{l}.0239168 \\
(.0476177) \\
\end{array}$ & $\begin{array}{l}.0218209 \\
(.0406313) \\
\end{array}$ \\
\hline SIZE & $\begin{array}{l}.1050209 * * * \\
(.0269986)\end{array}$ & $\begin{array}{l}.1334948 * * * \\
(.0250519)\end{array}$ & $\begin{array}{l}.1035046^{* * *} \\
(.0299958)\end{array}$ & $\begin{array}{l}.0747829 * * * \\
(.0249511)\end{array}$ & $\begin{array}{l}.0371863 * * \\
(.0150575)\end{array}$ \\
\hline PRIMARY & $\begin{array}{l}.2007037 * * * \\
(.0660285) \\
\end{array}$ & $\begin{array}{l}.0748801 \\
(.0496162) \\
\end{array}$ & $\begin{array}{l}-.0981961 * * \\
(.0539701)\end{array}$ & $\begin{array}{l}-.2079504 * * * \\
(.0467568) \\
\end{array}$ & $\begin{array}{l}-.4054071^{* * *} \\
(.0333267)\end{array}$ \\
\hline ENERGY & $\begin{array}{l}.1829112 * * * \\
(.0887933)\end{array}$ & $\begin{array}{l}.0514381 \\
(.1047918) \\
\end{array}$ & $\begin{array}{l}-.0747126 \\
(.1012019) \\
\end{array}$ & $\begin{array}{l}-.2620987 * * * \\
(.0851897)\end{array}$ & $\begin{array}{l}-.4306828 * * * \\
(.0643746)\end{array}$ \\
\hline GOOD & $\begin{array}{l}.235605 * * * \\
(.0855876)\end{array}$ & $\begin{array}{l}.1133341 \\
(.0930768) \\
\end{array}$ & $\begin{array}{l}-.0312022 \\
(.0948829) \\
\end{array}$ & $\begin{array}{l}-.2002294 * * \\
(.0793259)\end{array}$ & $\begin{array}{l}-.4142251 * * * \\
(.0548107)\end{array}$ \\
\hline PROPERTY & $\begin{array}{l}.2116374 * * \\
(.0961836)\end{array}$ & $\begin{array}{l}-.0065752 \\
(.1020555) \\
\end{array}$ & $\begin{array}{l}-.2221824^{*} \\
(.1071664)\end{array}$ & $\begin{array}{l}-.4678428 * * * \\
(.0897637)\end{array}$ & $\begin{array}{l}-.7035781 * * * \\
(.0737239)\end{array}$ \\
\hline SERVICES & $\begin{array}{l}.214817 * * * \\
(.0461295)\end{array}$ & $\begin{array}{l}.1075855 \\
(.0657561) \\
\end{array}$ & $\begin{array}{l}-.0001002 \\
(.0636199) \\
\end{array}$ & $\begin{array}{l}-.1739354 * * * \\
(.0516303)\end{array}$ & $\begin{array}{l}-.2210543 * * * \\
(.0349303)\end{array}$ \\
\hline $\mathrm{R}^{2} /$ Pseudo $\mathrm{R}$ & 0.3476 & 0.2653 & 0.2517 & 0.2499 & 0.3032 \\
\hline
\end{tabular}

This model provides stranded errors which are in parentheses. ${ }^{a}$ un balanced panel, ${ }^{*}$ Significant at $10 \%$ level, $* *$ Significant at $5 \%$ level, $* * *$ Significant at $1 \%$ level.

tive advantages of resorting to debt as a tax shield alternative to depreciation is lower for high level of leverage.

Table 2, shows that RISK is significantly and negatively associated with firm leverage levels in the quantiles $0.25,0.75$ and 0.90 . This finding is consistent with pecking order theory and trade-off theory, which suggest that the negative relationship between firm 

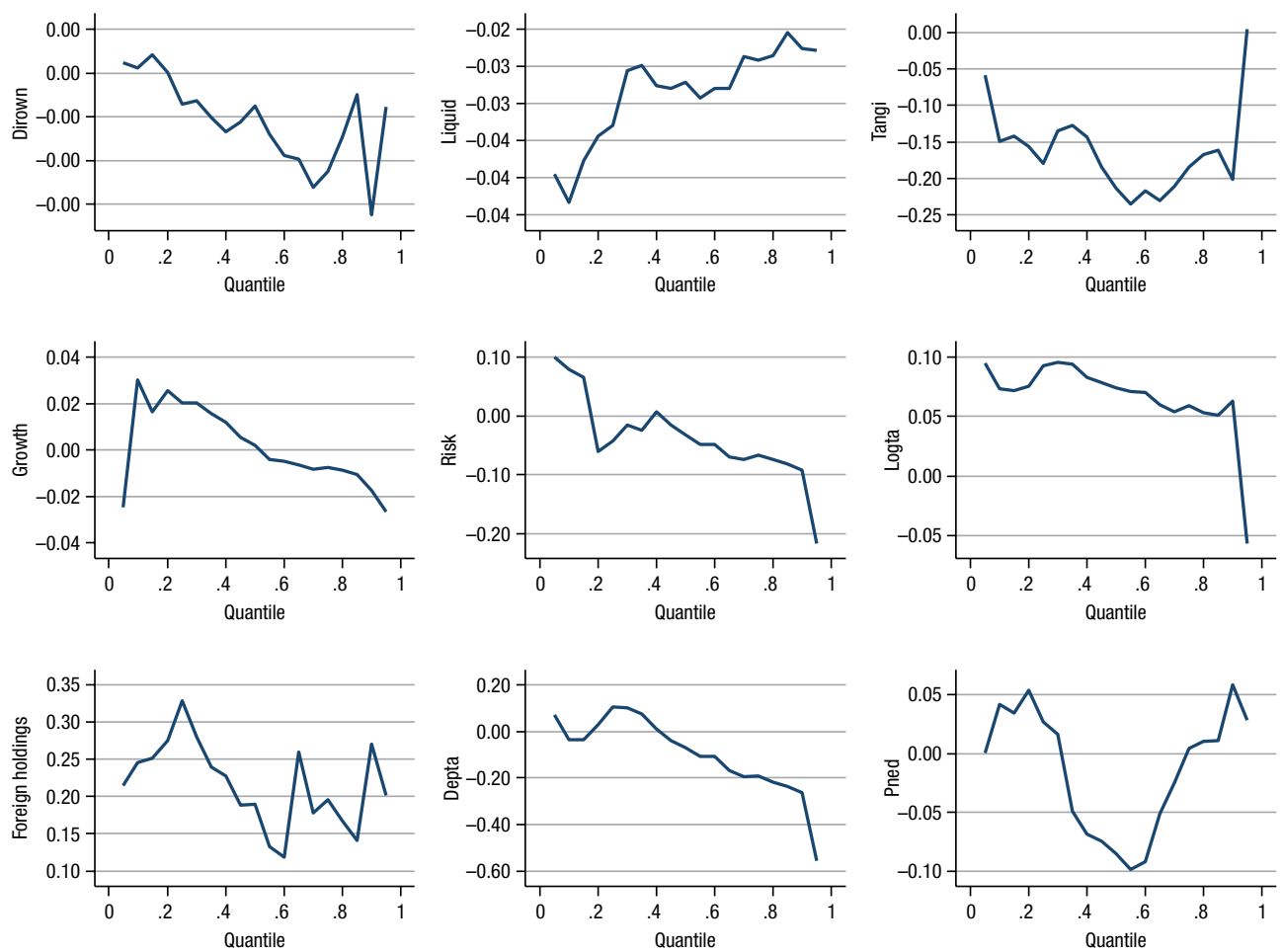

Fig. 1. Quantile regression results

risk and debt level increases with the volatility of income. This may be because firms with more volatile cash flows face high expected costs of financial distress which leads to use less debt in their capital structure. Moreover, high risk is detrimental from a shareholder perspective. Thus shareholders may force high risk firms to have low leverage. The coefficient of FOREIGN is significantly negatively related to firm leverage level in the quantile 0.90 . This may be due to foreign investors demanding management use low debt to avoid the bankruptcy risk in highly leveraged firms. The possible explanation for that is due to high information asymmetry between foreign owners and local managers, foreign owners may try to avoid having more debts in their capital structure after a certain level. Additionally, Wiwattanakantang (1999) explains the use of debt financing as disciplinary mechanisms for management is less adopted in foreign ownership, because foreign shareholders are more likely to actively monitor the company. The estimated coefficient of the PNED variable is not significant. This may be because though firms have a high number of non-executive directors, the directors are not independent or have less information availability. Based on the UK study, the Higgs Report (2003) also indicates that most non-executive directors are recruiting via personal contacts in UK. This practice may be similar in New Zealand. Hence non-executive directors may create a "rubber stamp board" approving CEO/chairperson board decisions without question. Therefore non-executive directors may have no impact on firm capital structure decision in New Zealand firms. The DOWN variable is also non-significantly related with 
capital structure proxy and reveals that there is no impact from non-executive directors and director ownership when determining New Zealand firm leverage levels.

Results indicate a significant positive relationship between firm size and firm leverage level throughout all quantiles. It may be that larger firms have a higher credit rating than their smaller counterparts. Therefore, it is easy to access external financing due to lower information asymmetry (Subadar et al. 2010). Furthermore, firm size is an inverse proxy for credit risk. Hence, the probability of bankruptcy is significantly low in large firms that can enjoy high debt levels in their capital structure. Finally, the industry dummy variables indicate significant impact on all quantiles. This indicates industry varying factors have significant impact on both low and high leveraged firms. This finding is consistent with Saksonova (2006), who finds the nature of the industry has significant impact on company assets and liquidity.

\section{Conclusions and implications}

This paper uses quantile regression analysis to identify how capital structure relations differ across firms at different quantiles of the leverage distribution. Moreover, this study finds firm-specific characteristics (i.e. tangibility, liquidity, risk, growth, tax-shield and firm size) play a significant role in determining firm leverage levels rather than corporate governance variables.

Another main implication of this study is the relevance of capital structure theories and financing as it applies to New Zealand listed businesses. The capital structure choices in emerging market firms can be determined by firm liquidity, tangibility, tax-shield, growth rate, risk, firm size and industry. However, these variables have different impact on different levels of leverage quantiles. Nevertheless, finance policies need to vary across firm type and firm characteristics, and should match the different borrowing requirements of listed firms.

\section{References}

Abor, J. 2007. Corporate governance and financing decisions of Ghanaian listed firms, corporate governance, International Journal of Business in Society 7(1): 83-92.

http://dx.doi.org/10.1108/14720700710727131

Agca, S.; Mansi, S. 2006. Takeover defences, managerial ownership, and firm leverage, SSRN. March 14, 2006. http://dx.doi.org/10.2139/ssrn.890745

Al-Najjar, B.; Taylor, P. 2008. The relationship between capital structure and ownership structure, Managerial Finance 34(12): 919-933. http://dx.doi.org/10.1108/03074350810915851

Alves, P. F. P.; Ferreira, M. A. 2011. Capital structure and law around the world, Journal of Multinational Financial Management 21: 119-150. http://dx.doi.org/10.1016/j.mulfin.2011.02.001

Bauer, P. 2004. Determinants of capital structure empirical evidence from the Czech Republic, Czech Journal of Economics and Finance 54(1-2): 2-21.

Berger, P. G.; Ofek, E.; Yermack, D. L. 1997. Managerial entrenchment and capital structure decisions, Journal of Finance 52(4): 1411-1438. http://dx.doi.org/10.2307/2329441

Bevan, A.; Danbolt, J. 2000. Dynamics in the determinants of capital structure in the UK, Working paper. University of Glasgow. 
Bevan, A.; Danbolt, J. 2002. Capital structure and its determinants in the UK - a decomposition analysis, Applied Financial Economics 12(3): 159-170.

http://dx.doi.org/10.1080/09603100110090073

Booth, L.; Aivazian, V.; Demirguc-Kunt, A.; Maksimovic, V. 2001. Capital structures in developing countries, Journal of Finance 56(1): 87-130. http://dx.doi.org/10.1111/0022-1082.00320

Bradley, M.; George, A. J.; Kim, E. H. 1984. On the existence of an optimal capital structure in developing countries, Journal of Finance 39 857-880.

http://dx.doi.org/10.1111/j.1540-6261.1984.tb03680.x

Brailsford, T. J.; Oliver, B. R.; Pua, S. L. H. 2002. On the relation between ownership structure and capital structure, Accounting and Finance 42(1): 1-26.

http://dx.doi.org/10.1111/1467-629X.00001

Buchinsky, M. 1998. Recent advances in quantile regression models: a practical guideline for empirical research, Journal of Human Resources 33(1): 88-126. http://dx.doi.org/10.2307/146316

Business Finance in New Zealand. 2004. Statistics New Zealand.

Cassar, G. 2004. The financing of business start-ups, Journal of Business Venturing 19(2): 261283. http://dx.doi.org/10.1016/S0883-9026(03)00029-6

DeAngelo, H.; Masulis, R. 1980. Optimal capital structure under corporate and personal taxation, Journal of Financial Economics 8(1): 3-29. http://dx.doi.org/10.1016/0304-405X(80)90019-7

Fattouh, B.; Harris, L.; Scaramozzino, P. 2008. Non-linearity in the determinants of capital structure: evidence from UK firms, Empirical Economics 34(3): 417-438.

http://dx.doi.org/10.1007/s00181-007-0128-3

Fattouh, B.; Scaramozzino, P.; Harris, L. 2005. Capital structure in South Korea: a quantile regression approach, Journal of Developmental Economics 76(1): 231-250.

http://dx.doi.org/10.1016/j.jdeveco.2003.12.014

Frank, M. Z.; Goyal, K. V. 2002. Testing the pecking order theory of capital structure, Journal of Financial Economics 67(2): 1-30.

Frieder, L.; Martell, R. 2006. On capital structure and the liquidity of a firm's stock, Working paper. Purdue University.

Gunasekarage, A.; Locke, S.; Ready, K.; Scrimgeour, F. 2006. Corporate governance practices of large firms in New Zealand and firm performance: an empirical investigation, in 19th Annual Australasian Finance and Banking Conference, 13-15 December, Sydney.

Gurunlu, M.; Gursoy, G. 2010. The influence of foreign ownership on capital structure of non-financial firms: evidence from Istanbul Stock Exchange, The IUP Journal of Corporate Governance 9(4): 21-29.

Harris, M.; Raviv, A. 1991. The theory of capital structure, Journal of Finance 46(1): 297-355. http://dx.doi.org/10.2307/2328697

Higgs Report. 2003. Freshfields Bruckhaus Deringer.

Jensen, M.; Meckling, W. 1976. Theory of the firm: managerial behaviour, agency costs and ownership structure, Journal of Financial Economics 3(4): 305-360.

Jensen, M. C. 1986. Agency cost of free cash flow, corporate finance and takeovers, American Economic Review 76(2): 323-329. http://dx.doi.org/10.1016/0304-405X(76)90026-X

Jordan, J.; Lowe, J.; Taylor, P. 1998. Strategy and financial management in UK small firms, Journal of Finance and Accounting 25(1): 1-27.

Kim, W. S.; Sorenson, E. H. 1986. Evidence on the impact of agency costs of debt on corporate debt policy, Journal of Financial and Quantitative Analysis 21(2): 131-144.

http://dx.doi.org/10.2307/2330733

King, M. R.; Santor, E. 2008. Trading places: impact of foreign ownership changes on Canadian firms, Journal of Banking and Finance 32(11): 2423-2432.

http://dx.doi.org/10.1016/j.jbankfin.2008.02.002 
Koenker, R.; Bassett, G. S. 1978. Regression quantiles, Econometrica 46(1): 33-50. http://dx.doi.org/10.2307/1913643

Koenker, R.; Hallock, K. 2001. Quantile regression, Journal of Economic Perspectives 15(4): 143-156. http://dx.doi.org/10.1257/jep.15.4.143

Lipson, M. L.; Mortal, S. 2009. Liquidity and capital structure, Journal of Financial Markets 12(4): 611-664. http://dx.doi.org/10.1016/j.finmar.2009.04.002

Mayers, S. C. 1984. The capital structure puzzle, Journal of Finance 34(3): 575-592.

http://dx.doi.org/10.2307/2327916

McConnell, J. J.; Pettit, R. R. 1984. Application of the modern theory of finance to small business firms, in P. M. Horvitz, R. R. Pettit (Eds.). Small Business Finance. 1 ed. Greenwich: JAI Press.

Mehran, H. 1992. Exective incentive plans, corporate control, and capital structure, Journal of FInancial and Quantitative Analysis 27(4): 539-560. http://dx.doi.org/10.2307/2331139

Michaelas, N.; Chittenden, F.; Poutziouris, P. 1999. Financial policy and capital structure choice in U.K. SMEs: empirical evidence from company panel data, Small Business Economics 12(2): 113-130. http://dx.doi.org/10.1023/A:1008010724051

Modigliani, F.; Miller, M. 1958. The cost of capital, corporate finance, and the theory of investments, American Economic Review 48(3): 291-297.

Morellec, E. 2001. Asset liquidity, capital structure and secured debt, Journal of Financial Economics 61(2): 173-206. http://dx.doi.org/10.1016/S0304-405X(01)00059-9

Mukherjee, C.; White, H.; Wuyts, M. 1998. Econometrics and data analysis for developing countries. New York: Routledge.

Myers, S. C. 1984. The capital structure puzzle, Journal of Finance 39(3) 575-592.

http://dx.doi.org/10.2307/2327916

Myers, S.; Majluf, N. 1984. Corporate financing and investment decisions when firms have information that investors do not have, Journal of Financial Economics 13(2): 187-221.

http://dx.doi.org/10.1016/0304-405X(84)90023-0

Myers, S.; Rajan, R. 1998. The paradox of liquidity, Quarterly Journal of Economics 113(3): 733-771. http://dx.doi.org/10.1162/003355398555739

Myers, S. C. 1977. Determinants of corporate borrowing, Journal of Financial Economics 5: 147-175. http://dx.doi.org/10.1016/0304-405X(77)90015-0

Noulas, A.; Genimakis, G. 2011. The determinants of capital structure choice: evidence from Greek listed companies, Applied Financial Economics 21(6): 379-387.

http://dx.doi.org/10.1080/09603107.2010.532108

Nuri, J. 2000. A study of capital structure in the UK: hotel and retail industries. Surrey University.

Pandey, I. 2001. Corporate dividend policy and behaviour: the Malaysian experience, Working paper No. 2001-11-01. Ahmadabad: Indian Institute of Management.

Prahalathan, B. 2007. The determinants of capital structure: an empirical analysis of listed manufacturing companies in Colombo Stock Exchange Market in Sri Lanka. Sri Lanka, University of Kelaniya.

Rajan, R. G.; Zingales, L. 1995. What do we know about capital structure? Some evidence from international data, Journal of Finance 50(5): 1421-1460. http://dx.doi.org/10.2307/2329322

Ramdani, D.; Witteloostuijn, A. V. 2010. The impact of board independence and CEO duality on firm performance: a quantile regression analysis for Indonesia, Malaysia, South Korea and Thailand, British Journal of Management 21(3): 607-626.

http://dx.doi.org/10.1111/j.1467-8551.2010.00708.x

Ramlall, I. 2009. Determinants of capital structure among non-quoted mauritian firms under specificity of leverage: looking for a modified packing order theory, International Research Journal of Financial and Economics 1(31): 1450-2887. 
Ross, G. C. 1977. The determination of financial structure: the incentive signalling approach, Bell Journal of Economics and Management Studies Spring: 23-40.

Saksonova, S. 2006. The analysis of company's capital and evaluation of factors, which influence creation of the optimal capital structure, Journal of Business Economics and Management 7(3): 147-153.

Schoubben, F.; Hulle, C. V. 2004. The determinants of leverage: differences between quoted and non quoted firms, Tijdschrift voor Economie en Management 49: 589-621.

Sheikh, N. A.; Wang, Z. 2011. Determinants of capital structure: an empirical study of firms in manufacturing industry of Pakistan, Managerial Finance 37(2): 117-133.

http://dx.doi.org/10.1108/03074351111103668

Smith, D. J.; Chen, J.; Anderson, H. D. 2010. The relationship between capital structure and product markets: evidence from New Zealand, in New Zealand Finance Colloquium, February, 2008, Palmerston North.

Stohs, M. H.; Mauer, D. C. 1996. The determinants of corporate debt maturity structure, Journal of Business Finance \& Accounting 69(3): 279-312.

Subadar, U. A. 2011. Capital asset pricing model: evidence from the stock exchange of Mauritius, The IUP Journal of Financial Economics 9(1): 24-40.

Titman, S.; Wessels, R. 1988. The determinants of capital structure choice, Journal of Finance 43(1): 1-19. http://dx.doi.org/10.1111/j.1540-6261.1988.tb02585.x

Um, T. 2001. Determination of capital structure and prediction of bankruptcy in Korea. Cornell University.

Van-der-Wijst, D.; Thurik, R. 1993. Determinants of small firm debt ratios: an analysis of retail panel data, Small Business Economics 5(1): 55-65. http://dx.doi.org/10.1007/BF01539318

Venkiteshwaran, V. 2011. Asset tangibility and corporate debt capacity - an empirical investigation, in SWFA Conference, 9-12 March, 2011, Houston, Texas.

Wen, Y.; Rwegasira, K.; Bilderbeek, J. 2002. Corporate governance and capital structure decisions of Chinese listed firms, Corporate Governance: an International Review 10(2): 75-83. http://dx.doi.org/10.1111/1467-8683.00271

Wiwattanakantang, Y. 1999. An empirical study on the determinants of the capital structure of Thai firms, Pacific-Basin Finance Journal 7(3-4): 371-403.

http://dx.doi.org/10.1016/S0927-538X(99)00007-4

Nirosha Hewa WELLALAGE is a Senior Lecturer in Finance at the University of Waikato Management School. Her main research interests are in the areas of corporate governance, corporate finance and small business finance. She is an active researcher and has published her findings in several international refereed journals.

Stuart LOCKE is Professor at Department of Finance, University of Waikato Management School, Hamilton, New Zealand, 3240. Stuart has a $\mathrm{PhD}$ in finance and a background in finance, economics, valuation and chartered accountancy. His current research interests are in corporate governance capital market movements, agribusiness finance, small business finance and personal financial planning. Research projects are ongoing in the governance, market movement, agribusiness finance and small business areas with multiple publications in 1999 through 2008. Stuart has held positions at universities in New Zealand, Australia and the United Kingdom. He has worked in banking in Australia and Singapore and with Treasury in Australia. Most recently, before joining Waikato Management School he was involved in Executive Education at Massey University with the MBA programme and the public sector management programmes in Samoa, Cook Islands and Tonga. Dr Locke currently teaches professional courses in finance and management. 